\title{
Obliczanie kosztów spawania z wykorzystaniem systemów informatycznych
}

\author{
Calculating welding cost using information systems
}

\section{Streszczenie}

Podstawowymi czynnikami wpływającymi na osiąganie zysku są koszty wytwarzania oraz cena sprzedaży. W związku z tym, że cena sprzedaży zależy od relacji między popytem a podażą, głównym źródłem zwiększania zysku firmy wytwarzającej konstrukcje spawane jest obniżka kosztów produkcji i/lub wzrost mocy produkcyjnej. Organizacja pracy oraz odpowiednie monitorowanie parametrów ekonomicznych zwiększa wydajność. Istotnym aspektem jest również szybkość i aktualność przekazywanej w firmie informacji. W artykule przedstawiono i scharakteryzowano strukturę kosztów spawania. Przedstawiono również oprogramowania wspomagające obliczanie kosztów spawania.

Słowa kluczowe: koszty spawania; obliczanie kosztów; wspomaganie komputerowe; systemy informatyczne

\begin{abstract}
The main factors affect the profit are production costs and selling price. Therefore, the selling price depends on the relation between supply and demand, the main source increasing the company's profit producing welded structures is to cut production costs and/or increase production capacity. Work organization and adequate monitoring of the economic parameters increases productivity. An important aspect is the speed and topicality of information which is transferred between departments in company. The article presents and characterized the structure of welding costs. It also presents the software which support the calculation of the welding costs.
\end{abstract}

Keywords: welding costs; costs calculation; computer aiding; information systems

\section{Wstęp}

Podstawowymi czynnikami wpływającymi na osiąganie zysku są koszty wytwarzania oraz cena sprzedaży. Producenci mają ograniczony wpływ na maksymalizację zysku poprzez podniesienie ceny danej konstrukcji spawanej. Zbyt wysoki koszt może spowodować utratę klientów natomiast koszt zaniżony może generować straty. W związku z tym, że cena sprzedaży zależy od relacji między popytem a podażą, głównym źródłem zwiększania zysku firmy wytwarzającej konstrukcje spawane jest obniżka kosztów produkcji oraz wzrost mocy produkcyjnej. Aby koszty produkcji obniżyć, na początku należy zdobyć wiedzę o ich głównych składnikach, miejscach ich powstawania, a także poznać procentowy udział poszczególnych składników kosztów w ogólnym koszcie wytwarzania. Daje to możliwość określenia, na którym etapie procesu produkcyjnego można najwięcej zaoszczędzić. Koszty wytwarzania powiązane są przede wszystkim z samym procesem - należy jednak pamiętać, iż etap, od którego w dużej mierze zależą całkowite koszty spawania, to etap projektowania. Badania przeprowadzone przez amerykańskich naukowców wskazują, że producenci, traktują zagadnienia kosztów spawania bardzo powierzchownie, nie zdając sobie sprawy ile pieniędzy wydają i dlaczego. Ponadto stosowana jest błędna metodyka obliczania kosztów spawania. Według ekspertów z Amerykańskiego Stowarzyszenia Spawalniczego (AWS) redukcja kosztów spawania powinna odbywać się poprzez optymalizację doboru technologii spawania, obniżenie ilości braków, ale także poprzez stosowanie automatyzacji, robotyzacji oraz komputeryzacji $[9,12,14]$.

\section{Czynniki wpływające na koszty spawania}

\section{Projektowanie połączeń spawanych}

Projektowanie konstrukcji spawanej jest ściśle powiązane z kosztami jej produkcji. Ponadto na etapie projektowania można wprowadzać zmiany bez ponoszenia strat. Po zatwierdzenie projektu stosunek kosztów do usunięcia błędów wynosi 10:1, w trakcie projektu technologicznego 100:1, w trakcie produkcji 1000:1, a po wypuszczeniu produktu na rynek 10000:1 (tab.1).

To projektant decyduje o gatunku materiału, rodzaju połączeń i długości spoin. Wielokrotnie ma możliwość wyboru między poszczególnymi rozwiązaniami, np. w fazie projektu możliwe jest wyeliminowanie złączy zbędnych z punktu widzenia technicznego, zastosowanie rowków spawalniczych omożliwiemałymkącieukosowania, unikanienadmiernychnadlewów, dostosowanie wymiarów spoin do cieńszego elementu, w odpowiednich miejscach zastosowanie spoin przerywanych zamiast ciągłych, eliminowanie złączy doczołowych $[14,15]$.

Mgr inż. Monika Restecka - Instytut Spawalnictwa.

Autor korespondencyjny/Corresponding author. monika.restecka@is.gliwice.pl 
Tablica I. Stosunek kosztów do usunięcia błędów w zależności od etapu wytwarzania Table I. Stosunek kosztów do usunięcia błędów w zależności od etapu wytwarzania

\begin{tabular}{|l|c|}
\hline W trakcie projektowania & 1 \\
\hline Po zatwierdzeniu projektu & 10 \\
\hline W trakcie projektu technologicznego & 100 \\
\hline W trakcie produkcji & 1000 \\
\hline Po wypuszczeniu produktu na rynek & 10000 \\
\hline
\end{tabular}

Tablica II. Orientacyjne współczynniki jarzenia się łuku dla podanych stopni mechanizacji procesu (\%) [17] Table II. Approximate coefficients of arc for a given degree of process mechanization

\begin{tabular}{|l|c|}
\hline Stopień mechanizacji & Orientacyjny współczynnik czasu jarzenia się łuku (\%) \\
\hline Spawanie ręczne elektrodami otulonymi & $20-30 \%$ \\
\hline Spawanie zmechanizowane & $35-50 \%$ \\
\hline Spawanie zautomatyzowane & $50-80 \%$ \\
\hline Spawanie zrobotyzowane & $70-95 \%$ \\
\hline
\end{tabular}

\section{Przygotowanie elementów do spawania}

W skład operacji związanych z przygotowywaniem elementów do spawania wchodzi czyszczenie, cięcie oraz składanie. Błędy popełniane podczas tych operacji wpływają na wzrost kosztów spawania oraz na jakość i koszty wytwarzania konstrukcji. Błędy te bezpośrednio wpływają na proces i często są niemożliwe do usunięcia podczas dalszego etapu produkcji. Warto zatem pamiętać o kilku istotnych kwestiach. Blachy lub inne elementy konstrukcji spawanej powinny być poddane procesowi czyszczenia przed, a nie po operacji spawania. Aby zapewnić powtarzalność składania i sczepiania elementów (jeśli to konieczne), należy stosować odpowiednie przyrządy i przymiary okresowo je sprawdzając. W przyrządach należy zaznaczyć łatwy do identyfikacji punkt odniesienia, ułatwiający powtarzalne pozycjonowanie elementu. $\mathrm{W}$ odniesieniu do operacji przygotowania elementów do spawania, jaką jest również cięcie, należy stosować racjonalną, z punktu widzenia wymagań klienta i kosztów metodę, pamiętając jednocześnie, że przy wysokich wymaganiach co do jakości konstrukcji finalnej, niskie koszty, ale równocześnie niska jakość cięcia ręcznego mogą być przyczyną problemów i wzrostu kosztów na dalszym etapie produkcji konstrukcji spawanej [13].

\section{Organizacja produkcji}

Koszty wytwarzania tej samej konstrukcji spawanej mogą różnić się w zależności od racjonalnego wykorzystania czasu pracy $w$ danym przedsiębiorstwie produkcyjnym. W określeniu stanu organizacji produkcji pomaga narzędzie o nazwie Techniczna Norma Czasu Pracy. Jest to obiektywnie niezbędny czas potrzebny na wykonanie całkowitej operacji spawania, przy założeniu normalnych i racjonalnych warunków pracy (rys. 1) [17].

W skład Technicznej Normy Czasu Pracy wchodzą takie czasy jak $[14,17]$ :

- czas główny spawania - czas zużyty na topienie się spoiwa i materiału rodzimego, w wyniku czego powstaje spoina,

- czasy pomocnicze związane z długością spoiny oraz z metodą spawania - czas przeznaczony na nastawianie parametrów spawania, wymianę elektrody lub szpuli drutu, czyszczenie spoiny, założenie i odłożenie maski itp.,

- czasy pomocnicze związane ze spawanym przedmiotem - czas przeznaczony na zamocowanie, obrócenie lub zdjęcie przedmiotu,

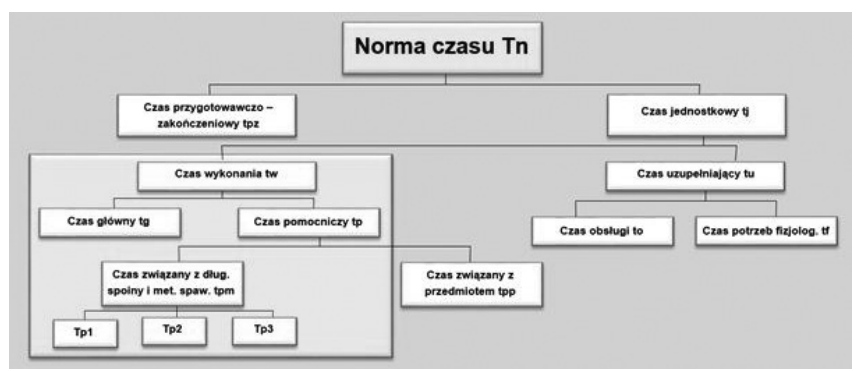

Rys. 1. Stosunek kosztów do usunięcia błędów w zależności od etapu wytwarzania

Fig. 1. The ratio of cost to remove the errors, depending on the stage of production

- czas uzupełniający - czas poświęcony na obsługę stanowiska,

- czas na potrzeby fizjologiczne,

- czas przygotowawczo-zakończeniowy.

Na poprawienie organizacji produkcji w przypadku procesów spawalniczych wpływa mechanizacja, automatyzacja i robotyzacja oraz wyposażenie stanowisk w odpowiednie urządzenia pomocnicze do pozycjonowania konstrukcji. O najbardziej efektywnym wykorzystaniu czasu pracy informuje współczynnik czasu jarzenia się łuku. Jest to stosunek czasu głównego do całkowitego czasu poświęconego na operacje spawania. Im współczynnik ten jest wyższy tym wyższa jest efektywność dobranej metody (tab. II) [17].

Warunki pracy, tj. zapewnienie właściwej wentylacji, wyposażenie spawacza w odpowiedni strój, czy też dostęp do miejsca wykonywanych spoin, mają również duży wpływ na wydajność pracy, a tym samym na koszty produkcji.

\section{Jakość}

Im wyższe wymagania dotyczące poziomu jakości i konieczności jego potwierdzenia tym wyższe będą koszty produkcji. Określenie optymalnego poziomu jakości możliwe jest dzięki analizie relacji pomiędzy wymaganą jakością a najniższymi kosztami produkcji konstrukcji spawanej. Jak wynika z rysunek 2, zbyt wysoki poziom jakości w stosunku do wymagań klienta również wiąże się ze stratami. Przykładowo wykonanie złącza spawanego łukowo o jakości D zamiast jakości B wpłynie znacznie na wymiar co w dalszym etapie może wpłynąć na podwyższenie kosztów produkcji $[16,18]$. 
Konkurencyjna kosztowo strategia jakości dla spawalnictwa polega na poszukiwaniu takich metod i parametrów spawania oraz organizacji pracy, które optymalizują poziom jakości złącza spawanego i całej konstrukcji spawanej.

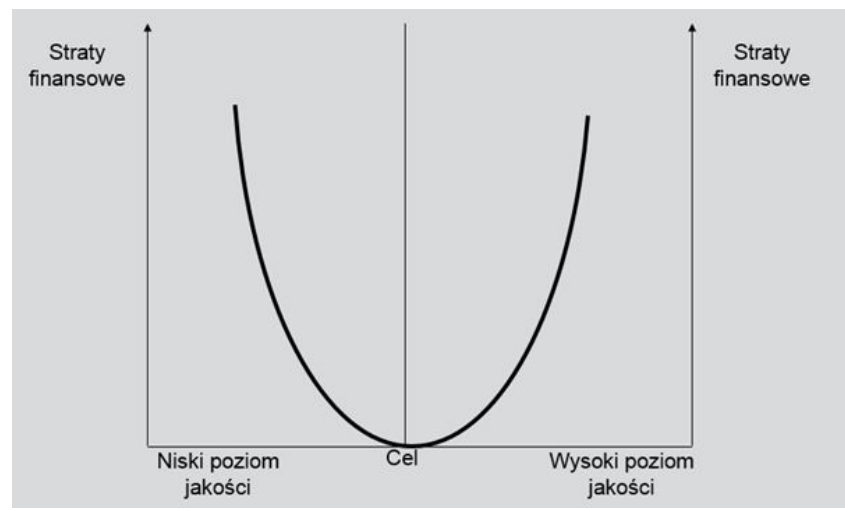

Rys. 2. Poziom jakości w funkcji strat finansowych $[17,18]$

Fig. 2. The level of quality in the function of financial losses

Spawalnictwo jest procesem specjalnym, w którym badanie wyrobu finalnego nie potwierdza w pełni jakości złącza spawanego. Specyfikacja wymagań dotyczących jakości dla procesów spawania jest zatem bardzo ważna. Ponadto nawet pełne i wysoce rozwinięte badania nieniszczące nie poprawią jakości wyrobu spawanego, dlatego też szczególnie istotne jest położenie nacisku na zapobieganie niezgodnościom spawalniczym [13].

\section{Niezgodności spawalnicze}

Do niezgodności spawalniczych zalicza się [4]:

- pęcherze,

- wtrącenia żużla,

- wtrącenia obcego materiału,

- przyklejenia,

- wycieki,

- podtopienia,

- wgłębienie w kraterze,

- brak przetopu,

- pęknięcia.

Wyżej wymienione niezgodności mogą być kontrolowane wizualnie przez operatora bezpośrednio podczas spawania lub sprawdzane po jego zakończeniu. Duża część niezgodności powstaje w wyniku nastawienia niewłaściwych parametrów spawania tj. natężenia prądu, napięcia, prędkości podawania drutu i prędkości spawania. Dodatkowo wpływ na wady spawalnicze ma np. zły kąt pochylenia uchwytu spawalniczego, kierunek spawania, odległość końcówki stykowej od materiału spawanego itd. Unikanie niezgodności spawalniczych i wad prowadzi do obniżenia całkowitych kosztów spawania, co można osiągnąć przez właściwe szkolenia w zakresie podnoszenia umiejętności i opanowania technik spawania oraz właściwy kompromis pomiędzy parametrami spawania, materiałami dodatkowymi i atmosferami ochronnymi [4].

Optymalizacja projektu i procesu spawania, zapobieganie niezgodnościom oraz inspekcja jakości procesu spawania, zamiast kontroli spoiny lub wyrobu spawanego to aspekty na które kładą nacisk nowoczesne metody zarządzania jakością w spawalnictwie. Dzięki stosowaniu nowych metod kontroli jakości możliwa jest redukcja kosztów spawania [13].

\section{Charakterystyka kosztów spawania}

Uzyskanie prawidłowego i pełnego obrazu kosztów spawania możliwe jest dzięki spojrzeniu na proces wytwarzania kompleksowo. Należy wziąć pod uwagę wpływ poszczególnych wskaźników charakteryzujących proces spawania, tj. grubość i rodzaj spawanego materiału, metodę spawania, zastosowane materiały dodatkowe, pozycję spawania, parametry rowka spawalniczego, dostęp do miejsca spawanego itp. Przystępując do analizy ekonomicznej danej produkcji, koszty spawania należy podzielić na dwie grupy: koszty pośrednie i koszty bezpośrednie. Do pierwszej grupy zagadnień zaliczyć można m.in. koszty zarządu, administracji, utrzymania ruchu, podatków itp. Do grupy drugiej natomiast zaliczane są $[6,12,18]$ :

1. Koszty materiałów dodatkowych tzn. elektrody, druty lite, druty proszkowe, gazy osłonowe oraz topniki

Na wysokość tych kosztów wpływ ma wiele czynników, m.in. właściwy dostawca pod względem stosunku jakości do ceny, dobór spoin pod kątem optymalizacji ilości wymaganego stopiwa oraz unikania przewymiarowania, wykonanie spoin sczepnych jako integralnej części spoin właściwych, unikanie nadmiernych nadlewów, zastępowanie spoin jednostronnych dwustronnymi, dbałość o szczelność instalacji gazowej itp.

Obliczanie kosztów materiałów dodatkowych zależy od metody spawania oraz masy spoiny $[2,13,18]$.

\section{Koszty robocizny}

Największy udział procentowy w strukturze kosztów spawania wykazują koszty robocizny. Redukcję tych kosztów można uzyskać poprzez zastosowanie mechanizacji lub robotyzacji procesu spawania oraz wysoko wydajnych metod spawania i materiałów dodatkowych o wysokim współczynniku stapiania. Ponadto istotne jest wyposażenie stanowisk spawalniczych w urządzenia pomocnicze tj. manipulatory czy obrotniki, ułatwiające dostęp spawacza do złącza spawanego dzięki czemu zaoszczędzone zostaną czasy pomocnicze. Unikanie odkształceń oraz wysoka jakość spawania wyeliminują konieczność prostowania wyrobu oraz napraw po spawaniu.

Podstawą do ustalenia kosztów robocizny jest czas spawania, zmierzony według Technicznej Normy Czasu Pracy. Jeśli nie ma możliwości wykonania pomiarów, obliczanie kosztów można wykonać z użyciem danych takich jak masa stopiwa, wskaźnik wydajności stapiania oraz współczynnik czasu jarzenia się łuku $[2,13,18]$.

\section{Koszty energii elektrycznej}

Moc elektryczna potrzebna na wykonanie określonych prac spawalniczych wpływa bezpośrednio na zużycie energii elektrycznej. Z ekonomicznego punktu widzenia najlepszym rozwiązaniem w kontekście kosztów energii elektrycznej jest stosowanie spawarek inwertorowych. W przypadku prac spawalniczych zużycie energii związane jest nie tylko z kosztami. Zbyt duża jej ilość obniża udarność i wpływa na powstawanie naprężeń, a te z kolei na odkształcenia. Dzięki metodom wysokoenergetycznym spawanie wykonywane jest $z$ dużymi prędkościami przy niskiej energii liniowej. Podgrzewanie spawanych elementów wymagających obróbki cieplnej przed lub w trakcie procesu również wpływa na zużycie energii. Warto zastanowić się nad zastosowaniem materiałów podstawowych i dodatkowych przy których nie ma konieczności wykonywania takiej obróbki $[1,13,18]$.

\section{Koszty urządzeń}

Koszt urządzeń to nie tylko cena danego urządzenia, ale także koszt amortyzacji, koszt remontów oraz koszt powierzchni produkcyjnej. Przy podejmowaniu decyzji o zakupie nowych urządzeń należy optymalnie, z punktu widzenia techniczno-ekonomicznego, dobrać technologię oraz metody spawania a także zanalizować oferty nie tylko pod kątem ceny urządzenia, ale także uwzględnić obsługę serwisową, gwarancje oraz dostępność części zamiennych $[4,13,18]$. 


\section{Komputerowe wspomaganie obliczania kosztów spawania}

Rzetelne obliczanie kosztów spawania nie należy do rzeczy prostych. Z tego powodu powstały narzędzia informatyczne ułatwiające takie obliczenia. Programy wspomagające obliczanie kosztów spawania pozwalają na określenie: kosztów materiałów dodatkowych, czasu i kosztów prac związanych ze spawaniem, kosztów energii elektrycznej, amortyzację urządzeń, dobranie parametrów, a także porównanie kosztów spawania poszczególnymi metodami. Dobór oprogramowania zależy od strategii firmy, jej możliwości finansowych oraz produkcyjnych. Dostawcy narzędzi komputerowych proponują szeroki wachlarz rozwiązań oprogramowań przeznaczonych do monitorowania parametrów ekonomicznych oraz obliczeń kosztów spawania wg danej normy. Poniżej przedstawione zostały przykłady oprogramowań wraz z ich funkcjami $[7,8,9,12,15]$.

\section{Analiza Kosztów PS}

Oprogramowanie Analiza Kosztów PS jest przeznaczone do analizy bezpośrednich kosztów spawania metodami 111,135 oraz 136. Program podzielony jest na kilka modułów: moduł metod spawania, moduł baz danych (baza danych stali niestopowych konstrukcyjnych, baza stali wysokostopowych chromowo-niklowych oraz baza danych materiałów dodatkowych do wszystkich metod spawania), moduł technologiczny (dostępny do wyboru rodzaj ukosowania: L, I, V, X, K, Y, U oraz pozycje spawania: PA, PB, PC, PD, PE, PF, PG) oraz moduł analizy kosztów, który zawiera dane dotyczące dobranych parametrów technologicznych wraz z ich korektą i oraz dane dotyczące parametrów ekonomicznych. Dodatkowo moduł przedstawia wyniki analizy technologicznej oraz ekonomicznej. Poniżej przedstawiono przykład analizy kosztów spawania dla metody 111 z użyciem oprogramowania Analiza Kosztów PS [10].
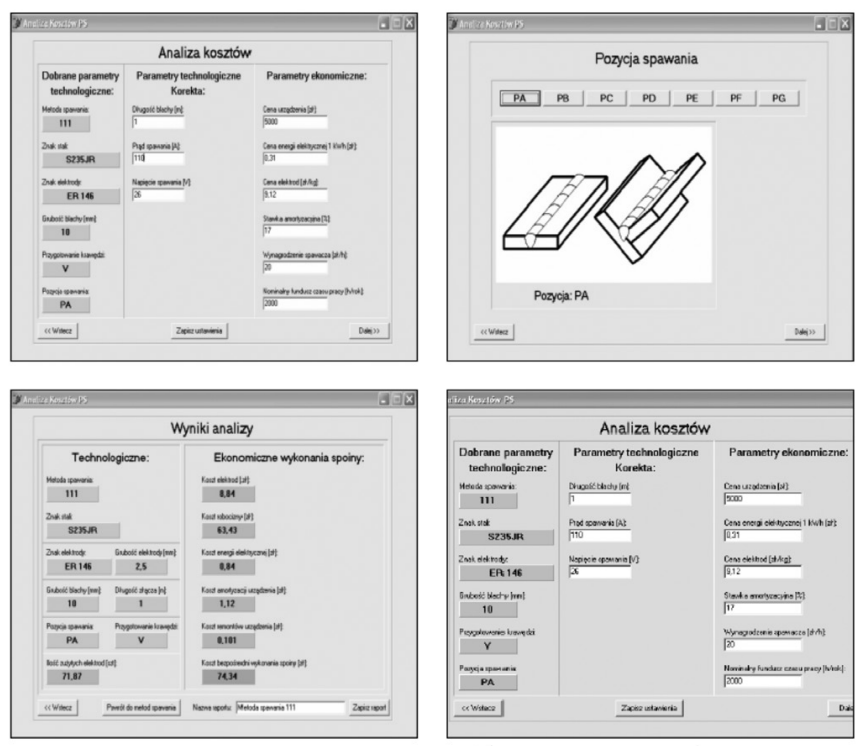

Rys. 3. Przykład analizy kosztów spawania przy użyciu oprogramowania Analiza Kosztów PS [10]

Fig. 3. Example analysis of the welding costs using Analiza Kosztów PS software

\section{Weld Metal Cost Calculator}

Weld Metal Cost Calculator to bardzo prosty program służący do obliczania kosztów związanych z materiałami dodatkowymi. Oprogramowanie zamieszczone jest na stronie internetowej firmy ESAB. Użytkownik może korzystać z oprogramowania on-line, bez konieczności pobierania i instalowania go na swoim komputerze. Aby obliczyć koszty materiałów dodatkowych należy wypełnić pola dotyczące np. rodzaju drutu, jego średnicy itp. Po odpowiednim wpisaniu potrzebnych danych program automatycznie oblicza koszty. Software jest przyjazny dla użytkownika, a jego budowa przypomina klasyczny formularz. Korzystanie z oprogramowania jest darmowe [21].

\section{Szybki Analizator Produktywności Spawania (QWPA)}

Inżynieria Wartości Dodanej (VAE), opracowana przez firmę ESAB, zapewnia dostęp do zespołu ekspertów zajmujących się analizą procesów produkcyjnych. Zespół ten do wykonywana analiz wykorzystuje podstawowe narzędzie, jakim jest oprogramowanie Quick Weld Productivity Analyzer (QWPA). Na hali produkcyjnej klienta wykonywane są niezbędne pomiary, a następnie wprowadzane do programu. Na podstawie tych danych QWPA symuluje różne możliwości potencjalnych udoskonaleń, prezentuje wyniki oraz możliwe oszczędności poprzez wdrożenie innowacyjnych rozwiązań. Na rysunku nr 4 pokazano zrzut ekranu oprogramowania QWPA [21].

\begin{tabular}{|c|c|c|c|c|}
\hline \multicolumn{4}{|c|}{ Ex Quick Weld Productivity Anabzer } & \multirow{2}{*}{ 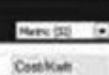 } \\
\hline 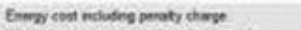 & 0.90 & Conkut & & \\
\hline 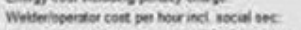 & xio & Conthor & s.o & conetron \\
\hline 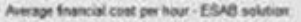 & & Cakimanes & & "Ceetrous \\
\hline 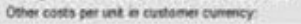 & & Contunt & & Cestivn \\
\hline 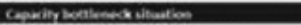 & & & 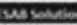 & \\
\hline 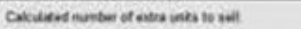 & & & 90 & alyowe \\
\hline Actial oso number donts nute & & & & anpres \\
\hline 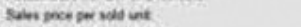 & & & & Aivevint \\
\hline 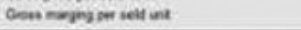 & & & & s \\
\hline 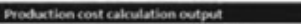 & Contemer solution & & 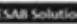 & \\
\hline Total production conk per meter welt: & $19, n$ & Coovm & 2,44 & coutm \\
\hline Totes production cost per enic & 190,4 & Contiont & $\ln _{\infty}$ & Coutine \\
\hline Production cout dinterence per unite & & & s.6. & conture \\
\hline Total production cout savinges per yeer: & 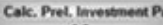 & Pay of fine: & sesss.os & Sainguyex \\
\hline Total peoduction cost surings in 5 : & 0.3 & Yean & $5 x$ & 5 \\
\hline 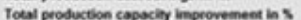 & Deperciesion pet rear. & $\operatorname{seg}$ & $10 \times$ & 5 \\
\hline
\end{tabular}

Rys. 4. Widok ekranu oprogramowania QWPA [21]

Fig. 4. Widok ekranu oprogramowania QWPA

Dodatkowym ułatwieniem przy wykorzystywaniu produktów firmy ESAB jest możliwość zalogowania się z każdego miejsca na świecie do systemu ESAB WeldCloud gdzie archiwizowane są dane technologiczne [21].

4. WeldCalc 2.0

WeldCacl 2.0 jest to system informatyczny przeznaczony do optymalizacji spawania przy użyciu stali Weldox, Domex i Hardox dla kombinacji różnych grubości. Dzięki możliwościom oprogramowania dokonywana jest optymalizacja procedur spawalniczych podczas pracy z ww. materiałami. Biorąc pod uwagę obciążenia cieplne i temperaturę podgrzewania $\mathrm{w}$ określonym etapie spawania

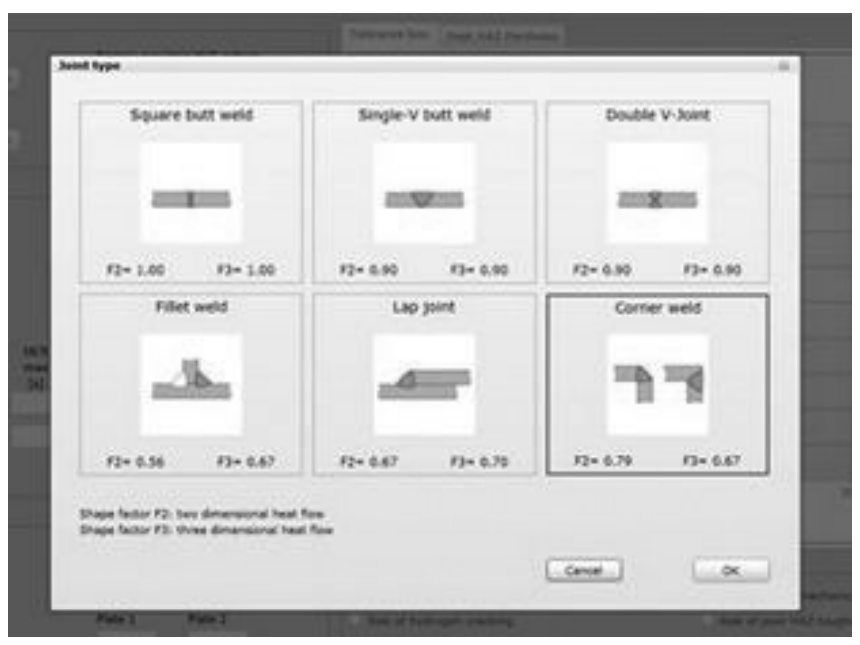

Rys. 5. Widok ekranu oprogramowania WeldCalc 2.0 [24]

Fig. 5. Screen View of WeldCalc 2.0 software 
oprogramowanie umożliwia optymalizację warunków brzegowych. Użytkownik ma łatwy dostęp do oprogramowania dzięki możliwości logowania on-line i zapisywania, otwierania i edytowania tego samego projektu. Program zalecany jest dla procesów MIG/MAG, TIG, spawania laserowego, hybrydowego oraz plazmowego [24].

\section{Costimator}

Costimator (rys. 6) to narzędzie, które służy do szacowania kosztów spawania na podstawie identyfikacji czasu spawania. Program jest przeznaczony dla różnych rodzajów spoin i dla różnych metod spawania. Ma budowę modułową, a każdy odrębny moduł służy do wspomagania obliczania kosztów. W zależności od potrzeb użytkownika dokonywana jest aktywacja poszczególnych modułów. Podstawowe oprogramowanie obejmuje szacowanie kosztów spawania, natomiast dodatkowe moduły wpływają na szczegółowość wykonywanej analizy ekonomicznej [23].

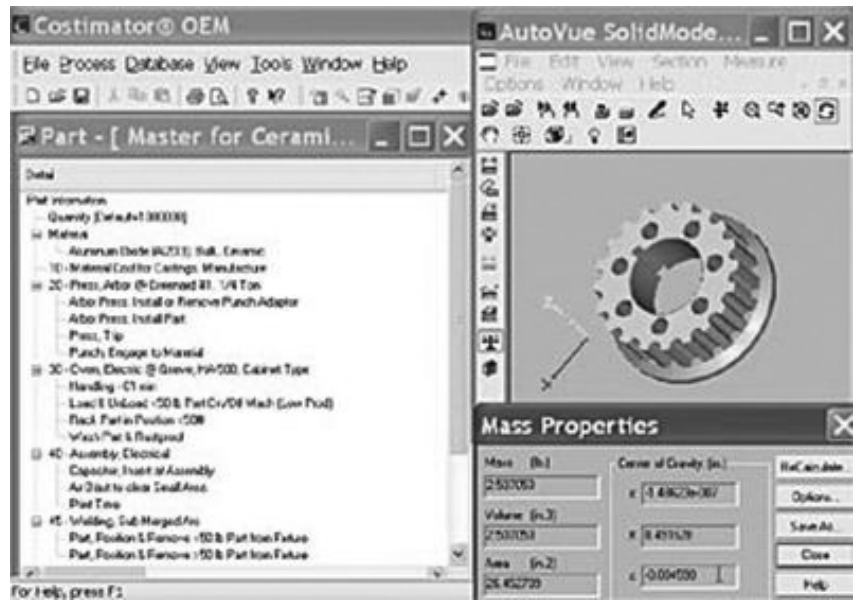

Rys. 6. Widok ekranu oprogramowania Costimator [23]

Fig. 6. Screen View of Costimator software

\section{Weld Cost Calc XL}

Weld Cost Calc XL (rys. 7) to oprogramowanie do obliczania kosztów spawania dla 10 różnych złączy. Software oparty na bazie programu Microsoft Excell jest przyjazny dla użytkownika. Przy wyborze odpowiedniego rodzaju złącza spawanego użytkownik może dokonać analizy porównawczej dla dwóch wybranych metod spawania. Jest to bardzo przydatna aplikacja z prostą i intuicyjną obsługą [20].

Wersję demo można pobrać ze strony autora progra$\mathrm{mu}$ (Brothersoft) natomiast pełna wersja to koszt około 80 dolarów. W wersji demo użytkownik ma możliwość wykonania obliczeń jedynie dla spoiny pachwinowej.

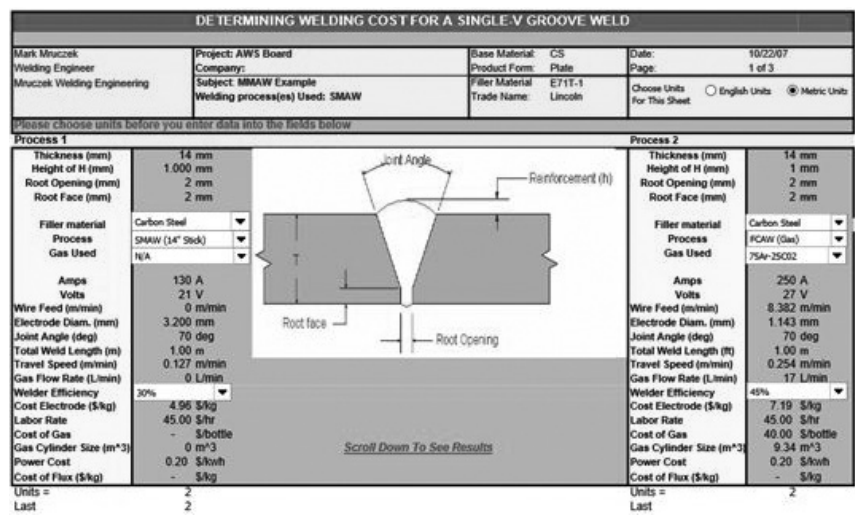

Rys. 7. Widok ekranu oprogramowania Weld Cost Calc XL [25]

Fig. 7. Screen View of Weld Cost Calc XL software
Podobnym oprogramowaniem działającym na takiej samej zasadzie jest program WeldCost Express, który kosztuje 99 dolarów [20].

\section{Welding Estimator}

Welding Estimator (rys. 8) czyli inaczej kosztorysant spawania, to program dzięki któremu można wykonać dokładne obliczanie kosztów spawania dla pojedynczego złącza według danych technologicznych. Software wspomaga pracę w zakresie dostosowania materiałów, kosztów pracy oraz kosztów eksploatacyjnych dla danej metody spawania. Program ma również wbudowany moduł odpowiedzialny za porównanie kosztów produkcji [15]. Najważniejszymi funkcjami oprogramowania kosztorysanta jest szczegółowe obliczanie kosztów spawania, dostosowanie czynników kosztowych dla danego regionu, możliwość generowania raportów materiałów wymaganych do wykonania danej spoiny, obliczanie eksploatacyjne oraz obliczanie ram czasowych według wytycznych i danych pobranych ze specyfikacji procesu. Oprogramowanie zostało zaprojektowane przez ekspertów z branży spawalniczej. Koszt inwestycji w tego rodzaju program to $845 €$ dla pojedynczego użytkownika [15].

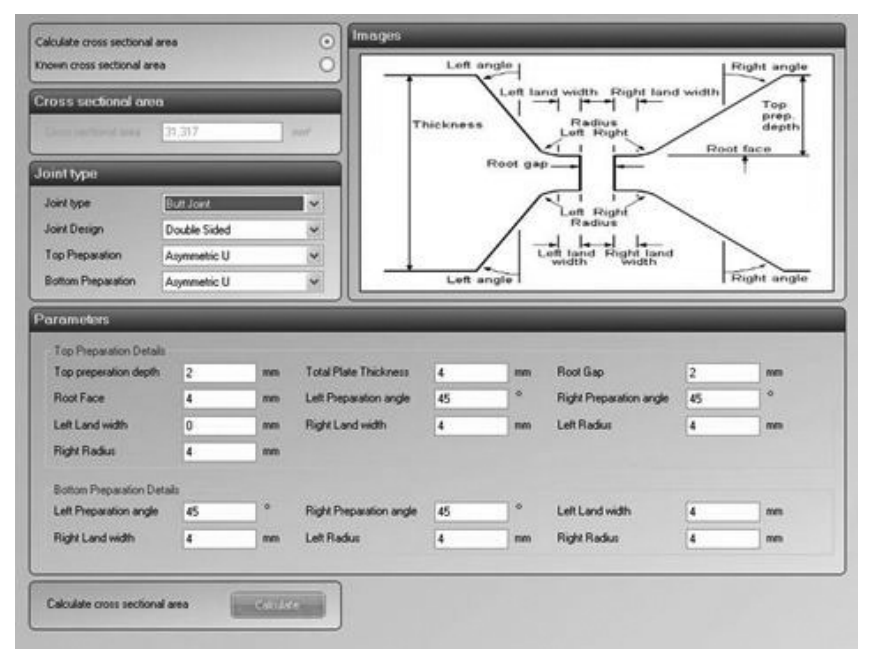

Rys. 8. Widok ekranu przedstawiający panel programu Welding Estimator [19]

Fig. 8. Screen View of Welding Estimator software

\section{Welding Pro}

Welding Pro to oprogramowanie do obliczeń spawalniczych. Wbudowany w aplikacji kalkulator kosztów pozwala na przeprowadzenie skomplikowanych obliczeń w prosty dla użytkownika sposób. Welding Pro daje możliwość obliczenia kosztów spawania dla wszystkich kształtów spoiny, dla wszystkich metod spawania. Program przeznaczony jest dla smartfonów w wersji darmowej [15].

\section{Weld Wizard}

Bezpłatna aplikacja firmy Fronius służąca do obliczania parametrów spawania takich jak powierzchnia przekroju na podstawie geometrii spoiny, jarzenie się łuku i rozpryski, parametry związane z energią elektryczną dla wybranych procesów spawalniczych. Dodatkowo Weld Wizard jest wyposażony w moduł służący do prostych obliczeń kosztów spawania i porównywarkę. Z aplikacji tej można korzystać przy użyciu smartfonów [22].

Niektóre kompleksowe rozwiązania informatyczne wspomagające procesy spawalnicze posiadają funkcje odpowiedzialne również za obliczanie kosztów spawania. Takimi oprogramowaniami są np. Weldassistant w wersji PRO-ISO (moduł BASIC-ISO + ewidencja spawaczy + kalkulator kosztów), WeldPulse (moduł WeldingCost) i wiele innych [15]. 


\section{Podsumowanie}

W niniejszym artykule przedstawione zostały sposoby obliczania kosztów spawania oraz wpływ poszczególnych czynników na te koszty. Najważniejszym aspektem w problematyce oszczędności kosztów wydaje się być konieczność kompleksowego spojrzenia na produkcję z uwzględnieniem wszystkich etapów wytwarzania konstrukcji i wyrobów spawanych.

Analizując aktualny stan w zakresie systemów informatycznych dla rodzaju produkcji, jaką jest spawalnictwo, można stwierdzić, że istnieje wiele rozwiązań przeznaczonych do monitorowania parametrów ekonomicznych oraz do obliczeń kosztów spawania wg danej normy. Programy te wspomagają obliczenia w zakresie: kosztów materiałów dodatkowych, czasu i kosztów prac związanych ze spawaniem, kosztów energii elektrycznej, amortyzację urządzeń, dobranie parametrów, a także porównanie kosztów spawania poszczególnymi metodami. Stosowanie tego rodzaju oprogramowań pomaga w sprawnej optymalizacji procesu i spojrzeniu na produkcję kompleksowo [12,18,15].

\section{Literatura}

[1] Ciechacki K., Giętka T., Chudziński M., Analiza czasu i kosztów spawania zbiornika magazynowego. Inżynieria i Aparatura Chemiczna nr 5/2012.

[2] Example of cost calculation in welding. Technical Sheets of EWF, 2007.

[3] Geisler R.: Estimating total welding costs. Fabricating Metalworking, April 2012.

[4] Grundmann J.: Jakość, wydajność i wynikające stąd koszty spawania stal węglowych w osłonie gazów aktywnych. Biuletyn Instytutu Spawalnictwa nr 5/2005.

[5] Hachicha W., Bouaziz Z.: Development of a welding cost estimation model based on the feature concept. Apem Journal nr 2/2007.

[6] Jarmai K., Farkas J.: Cost calculation and optimisation of welded steel structures. Journal of Constructional Steel Research, nr 2/1999.

[7] Martin N., Chen Hong-Mei, Kazman R. Cai Y., Xiao L., Silva Carlos V.A.: Manufacturing execution systems: A vision for managing software development. Journal of systems and Software, nr 101, march 2015.

[8] Masmoudi F., Bouaziz Z., Hachicha W.: Computer-aided cost estimation of weld operations. The International Journal of Advanced Manufacturing Technology $\mathrm{nr} 3 / 2007$.

[9] Miller K.D.: Determining the cost of welding. Welding Design and Fabrication $\mathrm{nr} 3 / 2004$

[10] Nowacki J., Pakos R., Kosek S.: Komputerowe wspomaganie obliczeń kosztów spawania. Przegląd Spawalnictwa nr 4/2007.

[11] OTC Daihen: Analyze your arc welding cost. Practical Welding Today, August 2007.
[12] Pfeifer T.: Metody oceny efektywności wdrożeń stanowisk do spawania zrobotyzowanego. Biuletyn Instytutu Spawalnictwa nr 3/2011

[13] Pilarczyk J., Zeman W.: Ekonomika i jakość w spawalnictwie. VI Krajowa Naukowo-Techniczna Konferencja Spawalnicza - Jakość w spawalnictwie, Międzyzdroje 8-10.05.2001, materiały konferencyjne.

[14] Praca zbiorowa pod red. J. Pilarczyka.: Poradnik Inżyniera -Spawalnictwo, tom 1. WNT Warszawa 2003.

[15] Restecka M.: Systemy informatyczne wspomagające procesy spawalnicze. Biuletyn Instytutu Spawalnictwa nr 3/2015.

[16] Silva C., Ferraresi V., Scotti A.: A quality and cost approach for welding proces selection. Journal of the Brazilian Society of Mechanical Sciences $\mathrm{nr} 3 / 2000$.

[17] Zeman W.: Materiały wykładowe na kurs Europejskiego Inżyniera Spawalnika, Instytut Spawalnictwa, Gliwice, 1998

[18] Zeman W.: Źródła obniżania kosztów w spawalnictwie. Biuletyn Instytutu Spawalnictwa $\mathrm{nr}$ 5/2000.

[19] Strona internetowa: www.aws.org

[20] Strona internetowa: www.e-spawalnik.pl

[21] Strona internetowa: www.esabna.com

[22] Strona internetowa: www.fronius.com

[23] Strona internetowa: www.mtisystems.com

[24] Strona internetowa: www.ssab.com

[25] Strona internetowa: www.twisoftware.com 